УДК 636.09.614:638.8

(C) 2012

Сачук Р. М., здобувач,

Демчук М. В., доктор ветеринарних наук, професор

Львівський національний університет ветеринарної медицини та біотехнологій ім. С. 3. Гжицького

\title{
ОБГРУНТУВАННЯ ВЕТЕРИНАРНОЇ ПРЕВЕНЦІЇ ТА ПОСТІЙНОДІЮЧОЇ ПРОФІЛАКТИКИ В УМОВАХ КРОЛІВНИЧИХ ГОСПОДАРСТВ
}

\section{Рецензент - доктор ветеринарних наук І. Д. Юськів}

На основі огляду літературних джерел та власних досліджень щзодо методів оцінки впливу комплексу чинників на здоров'я кролів запропоновано план загальної ветеринарної профілактики (ЗВП) кролівничим господарствам для розробки конкретної ветеринарної технології виробництва продукиії кролівництва. План включає такі важливі сучасні вимоги, як прогресивність технології виробництва, добробутність систем утримання кролів, збалан-

соване живлення доброякісними повноцінними кормами, обгрунтованість вибору породи та стан селекційної роботи зі стадом. На основі запропонованого плану ЗВП розпочато корекиію технології вирощування, утримання й розведення кролів у племінному репродукторі Украӥни «Екокрол»

Волочиського району Хмельницької області.

Ключові слова: план ЗВП, профілактика, добробут, ветеринарна технологія, превенція.

Постановка проблеми. В Україні $є$ всі можливості й умови для виробництва продукції кролівництва. Кролівництво - перспективна галузь тваринництва, яка $€$ додатковим джерелом забезпечення населення м'ясом, а промисловості хутром і пухом.

В останні роки в Україні у зв'язку з відсутністю сучасних наукових розробок, що стосуються питань повноцінної годівлі, технології утримання кролів, недостатнього рівня ведення племінної роботи і ветеринарного забезпечення, кролівництво занепало [11]. Досвід країн, які досягли значних успіхів у розвитку кролівництва, свідчить: ці досягнення зумовлені застосуванням альтернативних або розробкою та впровадженням ветеринарних технологій, в яких передбачені й дотримані екологічні, етичні, етологічні, вимоги добробуту тварин тощо, а на основі зоогігієнічних і ветеринарно-санітарних вимог розроблені й включені до технологічного процесу сучасні заходи комплексної профілактики (технологічної, постійнодіючої профілактики та превентивної терапії).

Аналіз останніх досліджень i публікацій, у яких започатковано розв'язання проблеми. Реалізувати весь комплекс організаційних за- ходів щодо опрацювання дієвої ветеринарної технології допоміг план загальної ветеринарної профілактики (ЗВП) у молочному скотарстві, свинарстві та собаківництві. Як зазначають дослідники даного напряму, в діючих племінних господарствах потрібно проводити корекцію технології та системи утримання тварин на основі впровадження плану ЗВП зворотної дії, що дасть можливість чітко розмежовувати етапи плану загальної ветеринарної профілактики в конкретній, прийнятій технології, визначити зони ризику й точки контролю для розробки методик превентивного та постійного профілактичного підходу для даних господарств [7, 9, 10].

Комплексному добробутному підходу, на основі плану ЗВП щодо опрацювання дієвої ветеринарної технології у кролівництві, вчені надають допокищо недостатньо уваги. У реалізації передбачених пунктів загальної ветеринарної профілактики у галузі кролівництва існує чимало напрацювань $[1,11]$, однак вони не враховують комплексних профілактичних особливостей технології.

Метою даної роботи стала розробка методичних підходів до вивчення сучасного стану технологій вирощування та утримання кролів в умовах кролівничих господарств, місце профілактики в даній технології, аналіз основних зон ризику (ЗР) й точок контролю (ТК) у відповідності до сучасних вимог прийнятого варіанта технології 3 метою внесення необхідних коректив.

Матеріали та методи дослідження. В основі матеріалу досліджень використано методичний підхід до вивчення наявного стану технології вирощування та утримання кролів в умовах кролівничих господарств і місця профілактики в даній технології. Враховано такі важливі сучасні вимоги, як прогресивність технології виробництва, добробутність систем утримання кролів, збалансоване живлення доброякісними повноцінними кормами, обгрунтованість вибору породи та стан селекційної роботи зі стадом. Саме на ці питання звернуто увагу в запропонованому 


\section{СТОРІНКА МОЛОДОГО ВЧЕНОГО}

плані ЗВП та його першому етапі - ветеринарній превенції [8].

В основу досліджень покладено методи ветеринарно-санітарного обстеження, опису та санітарно-статистичного.

Результати досліджень. Якість продукції кролівництва, що виробляється, залежить від багатьох факторів, серед яких першочергове значення мають гігієнічні нормативи, ветеринарно-санітарні вимоги і правила, а в країнах СС запроваджено ще й вимоги дотримання добробуту тварин [6].

За твердженнями М. В. Демчука та ін. (2008), дотримання гігієнічних нормативів, ветеринарно-санітарних правил і добробутних вимог покладено в основу плану ЗВП, який є підставою для розробки конкретної ветеринарної технології виробництва (див. схему) [8].

Перший етап плану ЗВП - ветеринарна превенція - пояснює не лише конкретні питання й $є$ обов'язковим для господарства, яке стоїть перед вибором найбільш відповідного для нього варіанту технології, системи, способу та методу утримання кролів, але й повинен включати комплекс питань, передбачених постійнодіючою профілактикою. Адже слід вибрати, замовити й одержати експертний ветеринарно-санітарний висновок на відповідність: чинним нормативним документів із технологічного проектування підприємств малої потужності звірівницьких і кролівницьких ферм - НТП-АПК 1.10.06.002-00. М., 2001; НТП ветеринарних об'єктів для тваринницьких, звірівницьких, птахівницьких підприємств. - М., 2002; будівель кролівничих господарств, їх обладнання; екологічно-кліматичну, профілактичну забезпеченість розташування ферми; безпечність грунтів, джерел водопостачання; безвідхідності та екологічності технологічного процесу. Крім того слід додати загальну селекційну характеристику стада та забезпечення кормової бази, включаючи джерела водопостачання $[3,4]$.

\begin{tabular}{|c|c|c|}
\hline $\begin{array}{c}\text { 1-й етап } \\
\text { Ветеринарна превенція, або } \\
\text { технологічна профілактика }\end{array}$ & $\begin{array}{c}\text { 2-й етап } \\
\text { Постійнодіюча профілактика }\end{array}$ & $\begin{array}{c}\text { 3-й етап } \\
\text { Превентивна терапія }\end{array}$ \\
\hline $\begin{array}{l}\text { - вивчення потреб, кон'юнктури } \\
\text { і шляхів збуту продукції кролі- } \\
\text { вництва, прогностично-еконо- } \\
\text { мічний аналіз, складання науко- } \\
\text { во обгрунтованого бізнес-плану } \\
\text { кролівничого господарства; } \\
\text { - екологічна експертиза полів, } \\
\text { території ферми, джерел води, } \\
\text { виробництва; } \\
\text { - вибір добробутної технології } \\
\text { виробництва продукції кролів- } \\
\text { ництва, системи і способу утри- } \\
\text { мання кролів; } \\
\text { - вибір проекту і прив’язка бу- } \\
\text { дівель; } \\
\text { - вибір породи, розробка ком- } \\
\text { п'ютерної селекційної програ- } \\
\text { ми; } \\
\text { - опрацювання технології виро- } \\
\text { бництва і постачання кормів; } \\
\text { - обладнання, машини, механіз- } \\
\text { ми, експертиза технології вироб- } \\
\text { ництва. }\end{array}$ & $\begin{array}{l}\text { - відповідність зробленого на } \\
\text { виробництві вимогам техноло- } \\
\text { гії; } \\
\text { - вивчення всіх етапів техноло- } \\
\text { гії виробництва: } \\
\text { а) будівлі та обладнання; } \\
\text { б) машини і механізми; } \\
\text { в) корми і годівля; } \\
\text { г) підлоги, каналізації, гноєве } \\
\text { господарство; } \\
\text { д) мікроклімат, температура, } \\
\text { вологість, рух повітря, мікроор- } \\
\text { ганізми, пил, токсичні гази; } \\
\text { е) вирощування (клітки, механі- } \\
\text { зми, дотримання вимог гігієни і } \\
\text { санітарії); } \\
\text { ж) окроли, вирощування моло- } \\
\text { дняку; } \\
\text { є) репродукція стада; } \\
\text { ж) зоогігієнічна, ветеринарно- } \\
\text { санітарна паспортизація і дис- } \\
\text { пансеризація підприємства, лі- } \\
\text { цензійна оцінка; } \\
\text { - впровадження GМР і НАССР; } \\
\text { - рівень підготовки й оцінка ро- } \\
\text { боти кадрів. }\end{array}$ & $\begin{array}{l}\text { - господарські, зоотехнічні (бо- } \\
\text { нітування), економічні, клініко- } \\
\text { фізіологічні методи оцінки і } \\
\text { виробництва; } \\
\text { - клінічна оцінка здоров’я кро- } \\
\text { лів, репродуктивних можливос- } \\
\text { тей тварин основного стада, рі- } \\
\text { вня природної резистентності, } \\
\text { стану імунологічного захисту; } \\
\text { - терапевтична диспансеризація, } \\
\text { вивчення функціонального ста- } \\
\text { ну йі обміну речовин в організ- } \\
\text { мі; } \\
\text { - клінічні, лабораторні, гемато- } \\
\text { логічні методи дослідження, } \\
\text { аналіз результатів. } \\
\text { - розробка плану превентивної } \\
\text { терапії. }\end{array}$ \\
\hline
\end{tabular}

Схема. План загальної ветеринарної профілактики для кролівничих господарств 
Якщо підприємство планує налагодити виробництво продукції кролівництва, виробничі потужності якого підлягають реконструкції, то мають бути поставлені такі ж вимоги експертної оцінки з питань ветеринарної превенції, як вище викладено. На діючих фермах оцінку території, грунтів, джерел водопостачання, безпосереднього технологічного процесу необхідно проводити у відповідності до вимог, передбачених планом санітарно-гігієнічної паспортизації [2].

Основним завданням другого обов'язкового етапу плану ЗВП (постійнодіюча профілактика) підприємств із виробництва продукції кролівництва - встановити і регулярно контролювати відповідність діючої технології нормативним зоогігієнічним та добробутним вимогам. Оцінка повноти реалізації даних вимог, метою яких є проведення постійного ветеринарно-санітарного і зоогігієнічного контролю за станом здоров'я кролів, входить в обов'язки інспекторів ветеринарної медицини. Тому в практичній роботі на підприємствах з інтенсивними технологіями ведення кролівництва використовують узагальнені методи оцінки і контролю функціональних можливостей організму тварин. Частина цих методів увійшла в обов'язкові в разі проведення та організації таких регулярних планових заходів селекційної роботи, яким $€$ бонітування і планова диспансеризація маточного племінного поголів'я [5].

На основі даних, одержаних селекціонерами, гігієністами, експертами FAO, встановлені мінімальні стандарти виробництва продукції кролівництва, зокрема і умов утримання для різних груп кролів. Контроль за їх дотриманням покладено на спеціалістів ветеринарної медицини, в обов'язки яких входить контроль за здоров'ям тварин і підвищенням продуктивності, згідно 3 генетичним потенціалом і умовами утримання. Для цього постійно використовуються індивідуальні клінічні методи, в тому числі, визначення (Т, П, Д). Проте для експресної оцінки здоров'я кролів, важливої в інтенсивних та надінтенсивних технологіях, клінічні методи, які застосовуються у племінних стадах, $\epsilon$ надто громіздкими.

Превентивна терапія $є$ третім етапом плану ЗВП у кролівництві. Сюди входять дані дослі-

\section{БІБЛІОГРАФІЯ}

1. Білий Л. А. Кролівництво [Текст] / Білий Л. А. - К. : Вища школа, 1990. - 180 с.

2. Гігієна тварин. Практикум [Текст] / Демчук М. В., Андрусишин Й. В., Гаврилець Є. С. [та ін.] // К. : Сільгоспосвіта. - 1994. - С. 67-84.

3. Гігієна тварин [Текст] / М. В. Демчук, М. В. джень, одержані в результаті як паспортизації діючої кролеферми, так і поточного бонітування та диспансеризації поголів'я кролів за програмою технологічного процесу, або зв'язані з потребами, що виникли в результаті аналізу даних вимушеної диспансеризації. Це прояви зниження продуктивності, включно 3 репродукційними i захисними можливостями кролів, отримане потомство 3 відхиленнями у розвитку, проявами незаразних, інфекційних чи інвазійних захворювань. Грунтується превентивна терапія на суворому дотриманні вакцинацій від ВГХК та міксоматозу, щоквартальній дегельмінтизації. Необхідно звернути увагу на такі ветеринарносанітарні заходи, як дезінфекція, дезінсекція та дератизація.

Висновки. Виходячи 3 аналізу даних джерел спеціальної літератури і власних досліджень стосовно методів оцінки впливу комплексу чинників на здоров'я кролів, запропоновано план загальної ветеринарної профілактики, що є підставою для розробки конкретної ветеринарної технології виробництва.

На даний час конкретний план ЗВП вводиться в технологічний процес племінного репродуктора 3 вирощування кролів «Екокрол» Волочиського району Хмельницької області. Проводиться паспортизація господарства, оцінка технології і стану ЗВП. Досліджуються параметри мікроклімату та проведення бальної оцінки у міні-фермах з утримання кролів. Визначається санітарно-гігієнічна оцінка якості води, збалансованості раціонів годівлі, які використовують у племінному репродукторі. У зв'язку з тим, що господарство використовує власну сировину для виробництва комбікормів, буде вивчено еколого-агрохімічний стан грунтів племінного репродуктора. На основі фізіологічного статусу організму кролів передбачено проведення диспансеризації поголів'я.

Отримані дані дають змогу провести чітке розмежування етапів плану загальної ветеринарної профілактики в прийнятій технології, визначити зони ризику й точки контролю, розробити методику превентивного та постійного профілактичного підходу для племінного репродуктора з вирощування кролів.

Чорний, М. П. Високос / Під ред. М. В. Демчука. - К. : Урожай, 1996. - 384 с.

4. Гігієна тварин [Текст] / М. В. Демчук, М. В. Чорний, М. О. Захаренко [та ін.] // Друге видання. Х. : Еспада, 2006. - 519 с.

5. Демчук М. В. Особливості методичних підхо- 
дів до оцінки здоров'я стада продуктивних тварин [Текст] / М. В. Демчук, П. В. Книшук // Збірник наук. праць ХДЗВА «Проблеми зооінженерії та ветеринарної медицини». Ветеринарні науки. - Вип. 20. - Х., 2009. - Ч. 2. - Т. 2. C. $180-187$.

6. Демчук М. В. Підвищення якості продукції кролівництва на окремих технологічних етапах [Текст] / М. В. Демчук, Р. М. Сачук // Науковий вісник ЛНУВМ та БТ ім. С. З. Гжицького. - Л., 2010. - Т. 12; №3 (45); Ч. 4. - С. 173-179.

7. Книшук П. В. Наукове обгрунтування плану ЗВП для корекції технології виробництва молока [Текст] / П. В. Книшук, М. В. Демчук, В. М. Ткачук // Науковий вісник ЛНУВМ та БТ ім. С. 3. Гжицького. - Л., 2009. - Т.11, № 3(42); Ч. 3. - С. 47-54.

8. Методичні вказівки з курсу «Загальна ветеринарна профілактика»; розділи «Добробут тварин» (Методи вивчення добробуту тварин при сучасних технологіях виробництва продукції) для підготовки фахівців 3 напряму 1305 «Вете- ринарна медицина» [Текст] / М. В. Демчук, О. В. Козенко, І. В. Двилюк [та ін.] // Л., 2008. $176 \mathrm{c}$.

9. Решетник $A$. О. Обгрунтування і зоогігієнічна оцінка корекції інтенсивної технології виробництва $з$ врахуванням стресочутливості організму свиней: автореф. дис. на здобуття наук. ступеня канд. вет. наук : спец. 03.00.13 «Гігієна тварин та ветеринарна санітарія» [Текст] / А. О. Решетник. - Л., 2009. - 20 c.

10. Стаєний О. В. Введення плану загальної ветеринарної профілактики прямої і зворотної дії в технологічний процес племінного розплідника собак [Текст] / О. В. Стаєний, М. В. Демчук // Науковий вісник ЛНУВМ та БТ ім. С. 3. Гжицького. - Л., 2009. - Т. 11, №3 (42); Ч. 3. - С. 131140.

11. Технологія виробництва продукції кролівництва та звірівництва : підручник [Текст] / В. І. Бала, Т. А. Донченко, І. Ф. Безпалий [та ін.] // Вінниця : Нова Книга, 2009. - 272 с. 